\title{
$\begin{array}{lllllllll}S & T & \text { U } & \text { D } & \text { I } & \text { A }\end{array}$
}

\section{S.C. Rowell}

Lithuanian Institute of History, Vilnius

\section{War and Piety in the Grand Duchy of Lithuania in the Late Middle Ages}

\begin{abstract}
As the prophet of the Gentiles, Job states, the life of Man upon earth is a warfare. During the fifteenth and early sixteenth centuries war against the Tatars and later the Turks and increasingly the Muscovites impinged considerably on the Catholic and Orthodox populations of the Grand Duchy of Lithuania. War and its consequences made their mark on devotions (to St George, St Casimir, the Ten Thousand Military Martyrs) and church and chantry building; pilgrimage contributions were sidelined for rebuilding churches as well as castles destroyed by the Tatars. The spoils of war were displayed publicly in Vilnius (Wilno) cathedral and thanksgiving for victory and intercession for the fallen took physical form in the building of churches by both Catholic and Orthodox leaders. Personal and patriotic memory of the dead was visualised publicly in religious buildings. Growing traditions of organising public processions around the city of Vilnius placed the Kletsk (Klecko) memorial church of St George clearly on the annual calendar. In the documentary record war was both a literary topos and a harsh everyday reality.

\section{Zarys treści}

Jak głosi prorok Hiob: „Bojowanie jest żywot człowieczy na ziemi”. W XV i XVI w. walki z Tatarami, a później Turkami i coraz częściej Moskwą znacznie utrudniały życie katolickich i prawosławnych społeczności Wielkiego Księstwa Litewskiego. Wojna i jej skutki wywierały wpływ na kult świętych (Jerzego, Kazimierza, Dziesięciu Tysięcy Rycerzy Męczenników) i budownictwo kościelne; datki pielgrzymie były przeznaczane na odbudowę zarówno kościołów, jak i zamków zniszczonych przez Tatarów. Łupy wojenne wystawiane były na widok publiczny w katedrze wileńskiej, a dziękczynienie za zwycięstwa i modły za poległych wyrażały się w fundowaniu kościołów przez przywódców tak katolickich, jak i prawosławnych. Osobiste i patriotyczne formy upamiętnienia zmarłych znajdowały materialny wyraz w obrębie budowli kościelnych. Umacniająca się tradycja organizowania procesji wokół miasta Wilna i uroczystości w kościele św. Jerzego (pomniku zwycięstwa bitwy pod Kleckiem) zajęły stałe miejsce w roku liturgicznym. W źródłach wojna ukazuje się nam jako literacki topos, a także jako codzienny znój.
\end{abstract}

Key words: Lithuania, Tatars, war, Catholic, Orthodox, church, memoria

Słowa kluczowe: Litwa, Tatarzy, wojna, katolicy, prawosławni, kościół, upamiętnienie 
As the Book of Job, quoted by Andrius Davainaitis (Andrzej Dowojna) in his endowment of the parish church at Iszczolna in 1515, says (in the Douay-Rheims translation) 'the life of man upon earth is a warfare, and his days are like the days of a hireling.' ${ }^{1}$ While the Biblical metaphor refers to the metaphysical fight between Good and Evil in the world, actual military conflict increasingly dominated Lithuanian life during the late fifteenth and sixteenth centuries as the Muscovite bear consolidated its forces after centuries of hibernation, preoccupied with establishing its power in northern and eastern Rus'. Lithuanian Catholic discourse was dominated by threats, alleged or real, posed by three main enemies, viz. the Tatars, pagans (native no less than foreign) and (Muscovite) schismatics. During the episcopacy of Albertus Tabor in Vilnius (Vilna, Wilno) (1492-1507) this diocese was described as being like a lamb surrounded by ravenous wolves, a see encompassed by raging Ruthenians, an enemy band that threatened the local and universal Roman Church. ${ }^{2}$ In ecclesiastical foundation acts and emoluments the danger allegedly posed by paganism is mentioned with increasing frequency after the third decade of the sixteenth century, as Catholics and Protestants argue fiercely over who is a true believer and who a false one. ${ }^{3}$ The Muscovite military threat and rejection of the Union of Florence, the strength of pagan survivals and revivals remain topics of interest to historians today. In this study our aim is to examine how far military topoi featured in Lithuanian Catholic devotion during the long fifteenth century (1387-1528). We will set aside the idea of Lithuania as a bulwark of Christendom, defending the Roman Church and her children in western and central Europe from the threat of the Turks and schismatic Ruthenians and concentrate rather on church-building, devotion in times of war and the use of the Tatar threat, perceived or real, as a means of attracting concessions from the Holy See. ${ }^{4}$

\footnotetext{
${ }^{1}$ Job vii.1; cf. Acta primae visitationis diocesis Vilnensis anno Domini 1522 peractae. Vilniaus Kapitulos archyvo Liber IIb atkūrimas, ed., introduction and commentary S.C. Rowell, Vilnius, 2015, Historiae Lituaniae fontes minores, vol. 8, no. 45 [40], p. 66: 'Quoniam, ut sacre scripture attestantur, militia est vita hominum super terram.

${ }^{2}$ Jan z Oświęcimia [Sakran], Elucidarius errorum ritus Ruthenici, Kraków, 1501; dedicating his work to Bishop Tabor, the Author notes how "in Lithuania Vilnensi sedi vigilantissime presidens, tumultuante turba Ruthenorum tue Romaneque ecclesie infensissimorum hostium circumseptus, velud agnus inter rapaces lupos".

${ }^{3}$ S.C. Rowell, 'Kaip šaukè, taip ir atsiliepè: XV a. lietuvių katalikų gyvenimas ir pagonybès liekanų mitas', in Lietuvos Didžiosios Kunigaikštystès istorijos kraštovaizdis. Moksliniu straipsniu rinkinys, skirtas profesorès Jüratès Kiaupienès 65-mečiui, ed. R. Šmigelskytè-Stukienè, Vilnius, 2012 pp. 295-320.

${ }^{4}$ Bulwark of Christendom - R. Trimoniene, 'Kryžiaus karų idèja XV a. II pusèje ir Lietuvos Didžioji Kunigaikštystė, in Kryžiaus karu epocha Baltijos regiono tautu istorinèje sąmonèje. Moksliniu straipsniu rinkinys, ed. R.R. Trimoniené and R. Jurgaitis, Šiauliai, 2007, pp. 223-32; S.C. Rowell, 'Naujieji kryžiaus žygiuotojai: LDK ir Bizantijos santykiai XIV-XV a. sandūroje. Ar Vytautas Didysis buvo Lietuvos kryžiaus žygių prieš turkus bei totorius pradininkas?', ibid., pp. 181-205.
} 
There is a legend which connects the foundation of the Franciscan friary at Kaunas (Kowno) and the Battle of Vorskla (Worskla). ${ }^{5}$ There are no grounds, except deduction from a foundation date given by a seventeenth-century historian, for claiming that Vytautas (Witold) founded the Franciscan friary in Kaunas in memory of the defeat of his international army by the Tatars at the River Vorskla in 1399. Darius Baronas shows that the seventeenth-century Lithuanian and Ruthenian father provincial Marcus Korona dated the foundation to 1400, even though the friar did not associate it ipsis verbis with the battle. ${ }^{6}$

The first major war memorial programme in Lithuanian Catholic history is probably the royal and grand-ducal donations which followed in the wake of the Polish-Lithuanian victory over the Teutonic Order in Prussia at Grunwald in July 1410. According to Długosz, a share of the Prussian standards captured by the victorious forces of Jogaila (Władysław II Jagiełło) and Vytautas during this battle along with property (gold and silver, books and liturgical vestments) seized by Polish and Lithuanian troops as they desecrated Prussian churches after the battle were handed over to Lithuanian parish churches and the cathedral of Saints Stanislaus and Ladislaus in Vilnius. These appear to have been destroyed finally during the great fire of Vilnius in 1530, according to Michalo Lituanus. ${ }^{7}$ Długosz also asserts that eight military banners from the army of Švitrigaila (Świdrygiełło) captured by the victorious forces of Žygimantas Kęstutaitis (Zygmunt Kiejstutowicz) at the Battle of Ašmena (Ashmiany, Oszmiany) on 8 December (the feast of the Immaculate Conception) 1432 were displayed as a sign of victory in Vilnius Cathedral and that a memorial church was built on the site of the battle. In fact a church belonging to the Franciscans already stood in Ašmena and it seems that at an unknown date in 1432 Žygimantas presented the friary with peasants owing a tribute of honey. ${ }^{8}$

\footnotetext{
${ }^{5}$ D. Baronas, Vilniaus pranciškony kankiniai ir ju kultas XIV-XX a., Vilnius, 2010, pp. 298-99; S.C. Rowell, 'Nevisai primintinos kautynès: ką byloja šaltiniai apie 1399 m. mūšst ties Vorsklos upe?', Istorijos šaltiniu tyrimai, 1, 2008, pp. 67-90.

${ }^{6}$ Baronas, Vilniaus pranciškonų, pp. 298-99.

${ }^{7}$ Ioannis Dlugossii, Annales seu cronicae incliti regni Poloniae, liber decimus et liber undecimus 1406-1412, ed. D. Turkowska, Warsaw, 1997, p. 134; of course some booty was given to Polish establishments too, such as the cathedral in Kraków - E. Potkowski, 'Monarsze dary książkowe w polskim średniowieczu - pogrunwaldzkie dary Jagiełły', in Ojczyzna bliższa i dalsza. Studia historyczne ofiarowane Feliksowi Kirykowi w sześćdziesiąta rocznicę urodzin, ed. J. Chrobaczyński et al., Kraków, 1993, pp. 359-73. See also K.J. Czyżewski, 'Marso aidai Krokuvos katedroje', in Kaip tai atsitiko Didžiajame mūšyje... Žalgirio atodangos, ed. V. Dolinskas and B. Verbiejūtė, Vilnius, 2010, pp. 44-66; V. Dolinskas, 'Vilniaus katedra - karinių pergalių minèjimo ir įamžinimo vieta', ibid., pp. 87-101.

8 'Signa hostium octo capta in ecclesiam Vilnensem in triumphi signum delata sunt... in loco itaque certaminis ecclesiam in honorem Beatissime Virginis Marie construit.' Ioannis Dlugossii, Annales seu cronicae incliti regni Poloniae, liber undecimus et liber duodecimus 1431-1444, ed. D. Turkowska, Kraków, 2001, p. 78. The language of this text is similar too, but not the same
} 
The Muscovite battle ensigns captured during the miraculous Lithuanian victory at Orsha (Orsza) in 1514 also hung in the cathedral. ${ }^{9}$ The role of Vilnius cathedral as a repository of war booty and national memorials should not come as a surprise. It was also the burial place of Lithuanian rulers and princes such as Vytautas, Švitrigaila, Mykolas Žygimantaitis (Michał Zygmuntowicz), Alexander Jagiellończyk and St Casimir.

The first known purpose-built church-cum-military shrine was founded near Ukmerge (Wiłkomierz) following the Battle of Pabaiskas (a Lithuanian version of the Polish Pobojsk) in 1435 which saw Žygimantas Kęstutaitis and his Polish allies trounce an army of Lithuanian rebels led by Švitrigaila, and the forces of the master of the Teutonic Order in Livonia. In gratitude for his victory and the saving of his throne Žygimantas founded a church on the battlefield around which a new township would grow up, known by the name of Pabaiskas (Pobojsk), and referred to in Latin records as Conflictus. It might be compared with the chapel of the Blessed Virgin Mary erected by the Grand Master on the field of Grunwald in 1413 in memory of the slain, or Battle Abbey, erected by William the Conqueror in commemoration of those who died during the Battle of Hastings in 1066. ${ }^{10}$ According to Długosz, the battle standards of the fallen Livonian army were taken to Vilnius Cathedral 'in signo tante victorie' and a church was built on the battlefield. The original foundation act does not survive but we have confirmations and extensions of it issued by Grand Duke Casimir in 1441, soon after his accession to the grand-ducal throne, and in 1492, as he neared his death. ${ }^{11}$ In the 1930s, apparently, old people still referred to the church as the Battle Church (Kovinè). ${ }^{12}$ Among the patrons of the church is the military hero St George. According to the records of the Visitation of the Diocese of Vilnius carried out by Canon Joannes Albinus in autumn 1522 the church was well-endowed and had (at least) four well-furnished chantry altars and appears to have been no less well-endowed than the grand-ducal foundation at Ukmergè or the Radvila

as Długosz's account of the battle of Pabaiskas (Pobojsk) - see below. For the 1432 Franciscan emolument, see KDKW, no. 127, p. 144.

${ }^{9}$ M. Čiurinskas, 'Karas ir kultūra Lietuvos didžiojoje kunigaikštysteje: 1514 metai', Senoji Lietuvos literatūra, 31, 2011: Istoriniai mūšiai senojoje Lietuvos raštijoje: Žalgiris ir Orša, pp. 127-80, esp. $146-49$.

${ }^{10}$ Grunwald chapel - S. Ekdahl, 'Pobojowisko grunwaldzkie i okolica w XV i XVI stuleciu', Studia Grunwaldzkie, 3, 1994, pp. 61-115, esp. 62-64; Battle Abbey - The Chronicle of Battle Abbey, trans. E. Searle, Oxford, 1980.

${ }^{11}$ KDKW, no. 164, p. 186; no. 168, p. 191; Casimir Jagiellonczyk renews Žygimantas Kęstutaitis' endowment, see 20 Jan. 1492 renewal, no. 374, p. 437. Ioannis Dlugossii, Annales seu cronicae incliti regni Poloniae, liber undecimus et liber duodecimus 1431-1444, ed. D. Turkowska, Kraków, 2001, pp. 156-60, banners taken to Vilnius cathedral - 'in signum tante victorie' - p. 159, church founded - p. 160 .

12 J. Matusas, Švitrigaila Lietuvos didysis kunigaikštis, Kaunas, 1938 (2nd edn - Vilnius, 1991), pp. 136-37. 
(Radziwiłł) church at Upninkai (Upniki). ${ }^{13}$ One of the altars was dedicated to the Ten Thousand Military Martyrs, a cult of wider popularity within the Grand Duchy and Poland. ${ }^{14}$ In 1514 Margaret of Pabaiskas, widow of Michael Pietkiewicz, confirmed her husband's 1503 bequest of 8 kopy of groats, while adding a gift of her small estate at Devithova to the altar of Ss Anne and James in St George's Church. ${ }^{15}$ In 1548 the now apparently derelict church was refounded by Sigismund Augustus.

13 'Ecclesia in Poboysko consecrata Item calices argentei cum patenis quatuor, unus ex eis deauratus. Item cruces argentee due: una maior, altera minor. Item ornatus solennes quinque et feriales etiam quinque, et tres antiqui. Item dalmatice due de kamcha. Item cappe due etiam de kamcha, una bona. Item antependia quinque bona. Item humerale de margaritis. Altariste in Poboysko Altarista Georgius tituli sancte Anne habet unum calicem non deauratum. Item pectorale argenteum parwm. Item duo ornatus: unus de adameszka rubea et alter de hathlas nigro. Item antependium de nigro hathlas. Altarista Albertus Lasnyewsky tituli Sancte Trinitatis habet unum calicem argenteum. Item crux argentea. Item ornatus duo de chamka burka et de sathyn nigro. Item antependia duo similiter de kamcha et de sathyn. Altarista Lucas tituli Decem milia militum habet unum tantum ornatum de kamcha et antependium similiter de kamcha; calicem non habet. Altarista Andreas tituli Nativitatis Marie habet unum calicem cum patena. Item pectorale argenteum. Item ornatus duo, antependium unum'. In 1553 the parish's taxable property 'Побоиско - сох шестнадцат, огородов одинадцат. Олтарникъ княз Павел - сохъ чотыры, огород один. Олтарникъ княз Ероним - сох чотыры [...]. Упъники - сох десет и пол, земля одна, городовъ тры. Олтарникъ - сох тры и пол, земъли сох тры, землъ тры, огородов семъ. Олтарникъ княз Станислав - соха одна. Олътарникъ княз Шчепа - сох тры и пол [...]. Вилкомере - сох чотырнадцат, земли две. Олтарник княз Закъровски - сох одинатцат. Олътарникъ княз Кглуховскии - сох осмъ и пол. Олтарник княз Либовскии - сох тры. Олтарникъ Марушовскии - сох осмъ, землъ шест. Олтарник княз Авъкгуштын - земли пол. Олтарникъ княз Кгроховски - сохи пол.; the amount due per sokh was five groats, five groats also per zemlia, two and a half groats per ogorod. These unpublished texts are presented in Acta primae visitationis, pp. 101-102, 166. Jerzy Ochmański considered Pabaiskas to be one of the parishes he classified as average in terms of wealth - Biskupstwo wileńskie w średniowieczu. Ustrój i uposażenie, Poznań, 1972, p. 103, Table III. Wealth is a relative and transient concept. In 1522 Ukmerge had four, Pabaiskas four and Upninkai no altars worthy of note; in 1553 the figures were six, two and three respectively.

${ }^{14}$ Take for example the cases of Dusetos (Dusiaty), Goniądz Castle, Turośn Kościelna, Pabaiskas and Zarasai (Jeziorosy) in the diocese of Vilnius, Budzieszy in the diocese of Lutsk (Łuck) - Acta primae visitationis, pp. 214, 222, 9, 102, 250, 255, 316, 199. To mark his 1349 victory over Ruthenia Casimir the Great founded the Church of the Ten Thousand Martyrs near his castle in Niepołomice (1350-1358). The cult of these legendary soldier martyrs of Ararat was popular too in Denmark, Sweden, Spain and Portugal during the late Middle Ages. St Vitus' Cathedral in Prague claimed some of their relics, as did several churches and religious houses in Poland - M. Starnawska, Świętych życie po życiu. Relikwie w kulturze religijnej na ziemiach polskich $w$ średniowieczu, Warsaw, 2008, pp. 47, 66, 78, 80, 89-91, 100, 142, 146, 180, 250. Relics of the martyrs were donated by Pope Alexander VI to Vilnius Cathedral in 1501 - KDKW, no. 505, pp. 614-15. The death of the martyrs is depicted in paintings by Dürer (1508) and Vittore Carpaccio (1515).

${ }^{15}$ A copy of the official copy made by the cathedral lawyer Adam of Kotra on 5 March 1514 is held in Vilnius, The Wróblewski Library of the Lithuanian Academy of Sciences [hereafter: Wróblewski Library], RS, Ms F 43-13633. The chantry priest was Georgius, parish priest of Salakas (Sołoki), 
Probably the first public memorial to victory over the Tatars is the Church of Our Lady of the Snows in the Carmelite Monastery of St George in Vilnius, which according to tradition was founded by Mikołaj Mikołajowicz Radziwiłł who fought alongside Mikhail Glinskii in battle against the Tatars at Kletsk in 1506 'ob memorabilem victoriam in ejus die festo nivium temporis felicis memoriae regis Alexandri germani nostri apud Klecko de tartaris reportatam. ${ }^{16}$ In 1525 St George's Church became the destination for a procession from the cathedral annually on St Mark's Day (April 25). ${ }^{17}$ The monastery thus became fixed in the public awareness of the sacred topography of the city (like the parish church, the Franciscan friary of the Assumption of Our Lady or the Hospice of Ss Job and Mary Magdalene). The church successfully commemorates the victory and the generosity of the Radziwiłł palatine who helped bring it about, while completely eliminating the memory of the other military commander (and later refugee), Mikhail Glinskii.

While thus far the churches we have seen built in the wake of battle have been Catholic, the victory of Lithuanian forces over the Muscovites at Orsha in 1514 was commemorated by both the Catholic king, Sigismund the Old and his commander in chief, the Orthodox nobleman Konstantin Ostrozkyi (Konstanty Ostrogski). Crossing the border of the Grand Duchy on his return from battle in September 1514 Sigismund gave orders for the endowment of a monthly mass in the first Catholic church he encountered (at Hajna) in honour of the Nativity

most likely Jerzy Taliat (Jurgis Taliatas), episcopal notary from 1508 - Lietuvos katalikų dvasininkai XIV-XVI a., ed. V. Ališauskas, T. Jaszczołt, L. Jovaiša and M. Paknys, Vilnius, 2009, Bažnyčios istorijos studijos, vol. 2, no. 1045, pp. 185-86. The Pietkiewicz family (Petkevičiai) also endowed the parishes of Maišiagala (Mejszagoła) and Paberžè (Podbrzezie). Cf. Acta primae visitationis, p. 211.

16 Wróblewski Library, RS, Ms F 43-21015, 31 July 1600 Sigismund III Vasa confirmed Sigismund the Old's 1514 charter for the Carmelite Monastery of St George in Vilnius - 'In nomine Domini amen. Ad perpetuam rei memoriam Sigismundus Dei gratia Rex Poloniae, Magnus Dux Lithuaniae, Russiae Prussiaeque etc dominus et heres, Significamus tenore presentium notitiam habituris, qualiter Magnificus Nicolaus Radziwillowicz palatinus Vilnensis ac cancellarius Magni Ducatus nostri Lithuaniae sincere nobis dilectus deduxit ad notitiam nostram, quod ipse ob devotionem singularem ad Virginem gloriosam Dei Genetricem se ob memorabilem victoriam in eius die festo Nivium temporis felicis memorie Regis Alexandri germani nostri apud Klecko de tartaris reportatam, Basilicam seu templum sub titulo Sanctae Mariae Nivis super Monte versus navigium fluvii Villae suis impensis fierri et construi procuravit totumque spatium illud sive aream ad se ac conjugem suam Elisabeth iure hereditario spectantem deputavit pro domo sive claustro ac monasterio aedificando. Quoniam recepit ac posuit viros religiosos fratres Ordinis Sanctae Mariae Carmelitarum, cui quidem monasterio sive conventui fratrum illic commorantium ipse dominus Nicolaus palatinus dedit perpetuoque inscripsit quoddam fundum sive praedium ac possessionem in parochia Rudaminensi [...]. Vilnae, feria quinta infra octavam Visitacionis Virginis Gloriosae, anno Domini millesimo quingentesimo quarto decimo [...]'.

${ }_{17}$ Wróblewski Library, RS, Ms F 43-210-1, Acta Venerabilis Capituli Vilnensis, vol. 1, p. 101, Polish summary in J. Kurczewski, Kościół zamkowy czyli katedra wileńska w jej dziejowym, liturgicznym, architektonicznym i ekonomicznym rozwoju, t. 3, Wilno, 1912, p. 27. 
of Our Lady, the feast on which the battle was fought. In return for a gift of land the parish priest was to sing in perpetuity these masses for the souls of the fallen, some of whose number were buried in the precincts of this church. ${ }^{18}$ The churches of the Grand Duchy are said to have rung their bells in celebration of the victory. ${ }^{19}$ There seems to be some confusion over whether Mikołaj Mikołajowicz Radziwiłł's foundation of a mansionary chapel in Goniądz in 1521 was intended as a memorial to the Orsha victory. In $1860 \mathrm{~W}$. Przyałgowski made such an association between the chapel and the battle, although the surviving foundation charter (Szpakowo, 7 July 1521) makes no such connection. In it Radziwiłł simply calls upon Our Lady to vindicate his foundation which he has made in praise of Her. J. Maroszek repeats this claim in a 1997 study of Goniądz, adding (without any grounds) that the gift is connected with Our Lady of the Snows (the patroness of St George's Monastery in Vilnius). ${ }^{20}$

The victory would be commemorated in the capital of the Grand Duchy itself by Prince Konstantin Ostrozkyi, ${ }^{21}$ who made use of the occasion to ask permission of the grand-duke and king to break Lithuanian law and build (or officially, to rebuild) two Orthodox churches, dedicated to the Holy Trinity and St Nicholas, in accordance with a promise he had made during the battle to present a thanks-offering for divine aid on the battlefield. ${ }^{22}$ The Volynskaia Kratkaia Letopis' redaction

${ }^{18}$ Acta Tomiciana, vol. 3, Posnaniae, 1853, no. 238, p. 188. 'Redeuntibus nobis ex prelio, quo hostem nostrum magnum ducem Moscovie contra fedus et iurisiurandum terras nostras occupantem fudimus, cum ad pirmam nostri ritus Romani ecclesiam in Hayna applicuimus, volentes immortali Deo ac eius intemerate matri, in cuius natali tanta nobis victoria cessit, quantam presens seculum non vidit, primordia laudis et gratitudinis nostre exhibere, agrum nostrum incipiendo a domo plebanali usque ad viam, que vadit penes ecclesiam et ex alia parte plebanali usque ad fluvium illuc fluentem honorabili Andree, plebano in Hayna ac successoribus ius omnibus ad tenendum et possidendum perpetuis temporibus dedimus, donavimus et cum omni iure et proprietate immunitati ecclesiastice adscribendum concessimus, ea videlicet ratione quod dictus plebanus ac successores ipsius debebunt exnunc et in perpetuum singulis mensibus cantare aut cantari facere Missam unam de nativitate [AT has die nativitatis] gloriose Virginis Marie cum memoria occisorum, qui ex prelio adducti ibidem tumulati sunt, pro animarum eorum salute et tante victorie memoria sempiterna. In cuius rei testimonium etc. Datum [Hajna, 17 Sept. 1514]'. Cf. Acta primae visitationis, pp. 91-93, 167, 171, 207, 208, 259.

${ }_{19}$ Čiurinskas, 'Karas ir kultūra', pp. 145-46.

${ }^{20}$ J. Kloza, J. Maroszek, Dzieje Goniądza w 450 rocznice praw miejskich, Białystok and Goniądz, 1997, Prace Białostockiego Towarzystwa Naukowego, no. 37, p. 26 and n. 92, p. 125-128.

${ }^{21}$ For a brief biography of Ostrozkyi, see H.M. Sahanovich, Ajchynu svaiu baroniachy: Kanstantsin Astrozhski, Mensk, 1992. On his church-building activities, see K. Chodynicki, Kościót prawosławny a Rzeczpospolita Polska. Zarys historyczny 1370-1632, Warsaw, 1934 (2nd edn - Białystok, 2005), pp. 80-81.

22 'In nomine Domini Amen. Ad perpetuam rei memoriam. Cum inter humane nature commoda nichil dignius memoria rerum gestarum $[\ldots]$ sublimius? Regum $[. .$.$] presencia, que perpetuo$ memoranda sunt, ne successu temporis a mortalium dilabantur noticia, sed literarum apicibus [et testium annotacione] ac sigillorum [appensione debent] perennare, Proinde Nos Sigismundus 
of the Lithuanian Chronicle contains an extended account of the battle which notes how the god-fearing hetman prayed in the Church of the Holy Trinity and St Nicholas at Orsha before combat began. ${ }^{23} \mathrm{~A}$ few years earlier Ostrozkyi had used

Dei gratia rex Polonie, Magnus dux Lituanie, Russie, Prussie Samogitieque etc [...] Significamus [tenore presencium], quibus expedit universis et singulis, quo[modo] [...] preterito lacessante nos et dominia nostra validis urg [...] scelerato et [...] magno Moskovie duce ad cuius reprimendos tam improbos conatur exercitum nostrum preside magnifico Constantino Ivanovicz duce Ostroviensi, castellano vilnensi et Magniducatus Lithuanie exercituum Luceoriensi et Vyniczensi Braslavieque capitaneo necnon marschalco terre Volynensis ex [...] dictusque Constantinus in agro Kropidlna, in quo cum dicto hoste mox [...] dum erat in [...] certorum consiliariorum nostrorum ceterorumque exercitus nostri magistratuus non minus religiose, quam solemniter vovisset duo templa seu oracula in civitate nostra Vilnensi unum in honorem Sancte et individue Trinitatis, aliud vero in honorem Sancti Nicolai lapide seu latere cocto et ab ipsis fundamentis erigenda et muro consummanda sub beneplacito tamen et ratihabicione nostra in quantum Deus Optimus Maximus nobis de dicto nephario hoste victoriam contulisset gentesque ipsius non minus efferatas quam numerosissimas in manibus nostris dedisset. Qua [...] re, quod felix faustumque sit, secuta, hoc est dicto hoste per nos ad intervectionem profugato tam sepedictus Constantinus quam etiam dicti consiliarii humiliter cum [...] nobis supplicarunt, quatenis ipsis predicti voti liberam exequucionem permitteremus. Et quia lege sancta et evangelica erudiri videmur ut et voveamus et reddamus vota nostra Deo predictis illorum de consilio consiliariorum nostrorum supplicacionibus [...] iustis et rationabilibus benigniter annuen[tes] supradictas ecclesias Sancte Trinitatis in colle vici, quo itur ad portam vie versus Miednyky [tendentis], ubi antiquius [templum] cum monasterio eiusdem tituli ritus [greci] erat ex ligno effectum, Sancti vero Nicolai quem magnum appellant [...] muro consumanda. In ipsisque omnia divina officia ritu ipsorum greco peragi $[\ldots]$ duximus permittenda presentibusque permittimus ut plenam [...] nostre admissionis et consensus non obstantibus constitucionibus consuetudinibusque in contrarium disponentibus, quibus pro hac vice derogamus: perpetue [...] harum quibus sigillum nostrum, quo tanquam Magnus dux Lituanie utimur, est subappensum testimonio litterarum. Datum Vilne feria quinta ipso die Sancti Andree apostoli anno Domini millesimo quingentesimo quarto decimo Regni vero nostri anno octavo, presentibus ibidem magnificis ac generosis Nicolao Nicolai Radivil palatino Vilnensi et Magni ducatus Lituanie cancellario, Gregorio Ostykowycz palatino et Stanislao castellano Troczensibus capitaneoque || Samogitarum [...] Alberto Gaschtoldo poloczensi, Ioanne de Zabrzezie Novohrodensi [...] Sopiha Transnarvensi et secretario nostro palatinis, Joanne Mykolaiovicz Radivil Magni ducatus Lithuanie marschalco et capitaneo Slonymensi, Niemyra Hrymalowicz Mielniczensi, Georgio Hlynicz Berestinensi capitaneis nostris et alys quam plurimis consiliarys, aulicis et marscalcis nostris sinceris et fidelibus nostris [dilectis. Datum] per manus venerabilis Stanislai Tharlo de Sczekarzovicze Cracoviensis, Wladislaviensis, Sandomiriensis ecclesiarum canonici, secretary nostri. Sigismundus Rex.' (a genuine parchment with a seal of the Grand Duchy attached, according to the editor). Sobranie drevnikh gramot i aktov gorodov Vil'ny, vol. 2, Vil'na, 1843, no. 6, pp. 13-15. The current location of the manuscript is unknown; the infelicities of the 1843 edition have been amended, where possible.

${ }^{23}$ Polnoe sobranie russkikh letopisei, vol. 35, Moscow, 1980, pp. 125-27. The manuscript came from the Suprasl Monastery and dates from the first half of the sixteenth century (ibid., p. 10). The author of the account makes use of St Nifont's Slovo k vernym, St Ephraim the Syrian's Parenesie and the Aleksandria (see Slovar' knizhnikov i knizhnosti Drevnei Rusi. XI - pervaia polovina $X I V$ v., ed. D.S. Likhachev, Leningrad, 1987, pp. 170-71, 296-99, and A. Brazgunoŭ, 'Perekladnaia literatura ŭ Vialikim Kniaztve Litoŭskim u XV-XVIII stagoddziakh', Senoji Lietuvos literatūra, 21, 2006, pp. 193-99. 
his good favour with the monarch to rebuild the Church of the Most Pure Virgin, which still stands by the River Vilnele (Wilenka) at the entrance to the transfluvial suburb of Užupis (Zarzecze). ${ }^{24}$ The Orthodox Church in Lithuania was clearly well-integrated into public life and in tune with Catholic devotional traditions (such as the building of hospices and chantry altars, and the formation of parish fraternities). The crude nineteenth-century imperial equivalence of Orthodoxy with Russia and Russia with Muscovy is virtually irrelevant to the history of the early-modern Grand Duchy (where Orthodoxy was associated primarily with Schism).

Both Catholic and Orthodox accounts of this battle view the conflict in metaphysical terms as a fight between Good (Lithuania) and Evil (Muscovy) in which representatives of the Heavenly Hosts take part on the Lithuanian side. Catholic sources (admittedly, the Polish Holy Cross Chronicle) note the presence of St Stanislaus, the patron of Polish unity and of the Jagiellonian regime in both Poland and Lithuania. Some scholars see an intimation of the intercession of St Casimir, the young Lithuanian royal prince, whose cult in Vilnius was growing towards universal acknowledgement, during the battle. However, surviving sources make no direct mention of the saint. By contrast, four years later in another battle against the Muscovites outside the city of Polotsk (Połock) in 1518 for Catholic soldiers the great defender was St Casimir, to whom the soldiers cry for aid, according to the later life of St Casimir by the Vilnius canon Gregorius Święcicki. ${ }^{25}$ In the earliest depictions of the saint he appears not as a milk-sop Jesuit school boy, but a warrior on a white steed as an iconic equivalent of St George or the Lithuanian heraldic device, Vytis (Pogoń). ${ }^{26}$

The effect of war with Muscovy was felt in personal devotional practice. In August 1500, before going of to war against Moscow ('equitans ad bellum contra perfidos Moscovitas'), a boyar named Gregorius Jakieylowicz sold a meadow to the Franciscan vicar in Vilnius for two score groats and land at Švirpliškès (Sz[w]yrpliszki). ${ }^{27}$ Three years later Grand Duke Alexander endowed the Holy Trinity chantry altar in Maišiagala with a plot of land, and three large barrels of seed for sowing therein along with the right to build an inn to be in the charge of the chantry priest Peter. The occasion prompting this royal gift was the diminution in income received by the altar as a result of a Muscovite attack. ${ }^{28}$

\footnotetext{
${ }^{24}$ On 4 July 1525 Ostrozkyi and his wife Tatiana Holszańska donated their estate at Šešuoliai (Szeszole) to this church in return for a panakhida (memorial prayers) for their souls on Friday evenings and Saturday mornings at two altars near the doors.

${ }^{25}$ Ankstyvieji Šv Kazimiero Gyvenimai, ed. M. Čiurinskas, Vilnius, 2004, pp. 142-46; M. Čiurinskas, 'Pergalès prie Oršos (1514) propaganda Europoje: Šaltinių apžvalga, literatūriniai ir kultūriniai aspektai', Senoji Lietuvos literatūra, 21, 2006, pp. 317-41.

${ }^{26}$ S. Maslauskaite, $\breve{s} v$ Kazimiero atvaizdo istorija, Vilnius, 2010.

${ }^{27} \mathrm{KDKW}$, no. 472 , pp. 556-57; probably at around the same time he donated a serf family to the Franciscans also valued at 300 score groats - no. 473, p. 557.

${ }^{28}$ Ibid., no. 552, pp. 652-53, 23 June 1503.
} 
The misfortunes caused by war are reflected in the testamentary evidence. In one 1506 will the Tatar threat is mentioned indirectly when the deceased's wife speaks of how in 1505 some of the benefactor's arms had been stolen by the Tatars (while Ivaškovičius [Iwaszkowicz] was attending the Sejm at Navahrudak [Nowogródek]). ${ }^{29}$

A survey of various surviving texts (church endowments, supplications sent to the Roman Curia) allow us to assert that the Tatars (of the Crimean Horde, although on occasion perhaps some from the Grand Duchy of Lithuania) were both an excuse for obtaining spiritual boons from Rome and a real military threat to certain parts of the country. ${ }^{30}$ The Grand Duchy did indeed stand across the land route between central Europe and the Black Sea where Franciscan and Dominican missions were established to deal with the Orthodox and Muslim worlds and Genoese and Venetian merchant colonies thrived in Kaffa (Feodosia). Even before the Turks seized that city in 1475 the materially indigent bishopric of Kaffa had become a titular entity. In 1472 the office was held by the archbishop of Lisbon's suffragan, but in the sixteenth century Lithuanian and Polish clerics assumed this dignity. Between 17 April 1532 and 1554 the suffragan bishop of Vilnius, Felix of Kazimierz OP, was also titular bishop of Kaffa. ${ }^{31}$

Lithuanian bishops elect, be they appointed to Vilnius, Medininkai (Miedniki), Lutsk or Kiev (Kyiv), often sought permission not to pay their otherwise compulsory biennial ad limina visits to Rome because they 'dwelled beyond the borders of Christendom among schismatics, Tatars and Ruthenians' and were in receipt of meagre income. Similar excuses would be presented by those seeking permission to hold several benefices, including posts as canon in other sees. ${ }^{32}$ There appear to have been fewer such claims made by Polish ordinaries in dioceses bordering on Tatar lands (such as Lwów [Lviv], Przemyśl, or Chełm).

${ }^{29} 10$ May 1506 will of Elżbieta Andruškaitė-Tautgirdaitė (Andruszkówna-Towtgirdowiczówna, Elizabeth Andree Thowtgirdowitz), widow of Albertas Ivaškovičius - ibid., no. 601, pp. 714-18, p. 717: 'arma mariti sui omnia nuper in dieta Novogrodensi anno proxime preterito celebrata, quedam per Tataros rapta, quedam in flumine Nyemyen mersa sunt'. Elżbieta's ancestry (Tautgirdaite, rather than Sakaite (Sakowiczówna) is confirmed by a supplication text, see Acta primae visitationis, p. 242.

${ }^{30}$ S.C. Rowell, 'XV a. LDK ir totorių santykiai Katalikų Bažnyčios akimis XV a.: prielaidos ir poveikis', in Vidurio rytų Europa mūšio prie Mèlynuju Vandenu metu, ed. V. Jankauskas and V. Nagirnyy, Kaunas and Kraków, 2013, Colloquia Russica, ser. 2, vol. 2, pp. 227-33.

${ }^{31}$ R. Jasas, Pergamentu katalogas, Vilnius, 1980, no. 206, p. 87 - 1515 mention of James, suffragan bishop of Vilnius; no. 429, p. 171 - 1540, Bp Felix of Kaffa. Cf. K. Eubel, Hierarchia Catholica medii [et recentioris] aevi, vol. 2, Münster, 1914, p. 117; vol. 3 (1924), p. 145.

${ }^{32}$ Bullarium Poloniae, vol. 7, ed. I. Sułkowska-Kuraś, S. Kuraś et al., Rome and Lublin, 2006, nos 541, 546, 580, 711; KDKW, no. 102, p. 128; no. 140, pp. 158-59; Vetera Monumenta Poloniae et Lithuaniae gentiumque finitimarum historiam illustrantia, vol. 2 [hereafter: VMPL II], ed. A. Theiner, Romae, 1861 (2nd edn - Osnabrück, 1969), no. 391, p. 363; 353, pp. 322-23. 
Lithuanian rulers, especially Casimir Jagiellończyk and his son and direct heir Alexander, succeeded in obtaining papal permission to divert income from local papal taxes (such as Peter's Pence) into the state treasury. For example in September 1508 Pope Julius II allowed Sigismund the Old to take two thirds of the monies collected for repair work to St Peter's Cathedral for local use in assuaging the aftermath of the Glinskii Rebellion; three years earlier the pope had allowed Grand Duke Alexander to divert Peter's Pence for ten years to rebuild churches and castles destroyed by the Tatars, giving precedence in this matter to the rebuilding of the fortress at Kamy'anets Podills'kyi (Kamieniec Podolski). ${ }^{33}$

As we know, from the beginning of the fourteenth century every fifty, and later every twenty-five years were held by the Roman Church to be jubilee or holy years when special indulgences would be offered to pilgrims to Rome or specified local basilicas, if travel to Rome proved too dangerous. ${ }^{34}$ In 1450 Casimir Jagiellończyk obtained an indult to transfer pilgrimages to the eternal city to those who offered the same amount of money as a Roman pilgrimage would have cost to visiting the cathedrals of Gniezno, Kraków, Lwów, or Vilnius. Half the monies raised would be set aside for fighting against the Tatars and only one quarter would be sent to Rome. Half a century later Pope Alexander VI permitted Vilnius Cathedral to collect jubilee offerings to fund wars against the Turks, Tatars and other infidels. ${ }^{35}$ It seems that such a redirection of funds was not sought or given in 1475, the year when Paul of Cizov, a priest from the diocese of Kiev, made the holy year pilgrimage to Rome. ${ }^{36}$ Could it be that Casimir Jagiellończyk's hopes for peaceful relations with the new Crimean khan, Mengli Girej, temporarily overcame fears of the threat posed from the steppes and the need to gather more ecclesiastical funds to pay for secular policy? ${ }^{37}$

In September 1482 after Moscow's ally Mengli Girej had seized and ravaged the seat of a Catholic bishop and Orthodox metropolitan in Kiev, Casimir asked more insistently for aid from Rome. On 7 November Sixtus IV proclaimed a crusade bull against the Turks, sending a copy of the bull to Polish and Lithuanian Bernardines (as crusade agents) and to leaders of Church and State in Casimir's realms, including Palatine Martynas Goštautas (Marcin Gasztołd) of Trakai (Troki), the Vilnius palatine Alekna, bishop Andreas of Vilnius and the Kievan ordinary, then languishing in Tatar captivity. On 10 December the pope announced financial aid

\footnotetext{
${ }^{33}$ VMPL II, no. 350, p. 325-26; 327, pp. 303-304.

${ }^{34}$ J. Smołucha, 'Udział pielgrzymów z Królestwa Polskiego i Wielkiego Księstwa Litewskiego w obchodach średniowiecznych jubileuszów chrześcijaństwa', Nasza Przeszłość, 93, 2000, pp. 5-21.

${ }^{35} \mathrm{KDKW}$, nos 200, 201, pp. 227-28; 206, p. 234; 1501 - pp. 588-90.

${ }^{36}$ VMPL II, no. 221, pp. 179-80.

${ }^{37}$ Ioannis Dlugossii, Annales seu cronicae incliti Regni Poloniae. Liber duodecimus 1462-1480, ed. D. Turkowska, Kraków, 2005, pp. 358-61.
} 
for war against infidels, especially the Tatars. ${ }^{38}$ On 1 March 1483 Sixtus issued Casimir with an indulgence for those who join in the struggle against the Turks. The pontiff mentions the king's intention to rebuild Kiev, a great and populous Ruthenian city, where the Turks (sic!) and Tatars had ravaged and burned churches and houses, slaughtering the inhabitants, taking captive the bishop, priests, men, women and children. The king had redeemed the bishop. We could mention other high ranking Tatar victims - Jan Chodkiewicz, palatine of Kiev and his wife and daughter. ${ }^{39}$ One gentleman from the Diocese of Lutsk, Stanisław Kunaty's son Mikołaj of Wyrozęby, patron of the church of the Holy Trinity, St Anne and St Matthew in that village, languished in Tatar captivity for twelve years after his capture at Kiev. During his imprisonment Mikołaj pledged to go on pilgrimage to Rome if he were released. In 1496 Mikołaj enlisted the support of King John Albert, Grand Duke Alexander and Cardinal Frederick Jagiellończyk in his plea to the pope to send relics to his parish church. ${ }^{40}$ This is a clear example of how Tatar actions in the Grand Duchy came to be reflected in popular devotion. In a slightly different way the Orthodox Church in Moscow benefited from the Tatar destruction of Kiev, when Ivan III successfully asked Mengli Girej to send him the chalices stolen from St Sophia's Cathedral in Kiev during the sacking of the city. ${ }^{41}$

Public memory of Tatar depredations may have been strongest in Orthodox tradition whereby the monastery at Kupiatsichy (Kupiatycze) in the Duchy of Pinsk claimed to have an icon of Our Lady which had suffered during the Tatar incursions into Rus' in the 1240s and was found by a young pilgrim named Joachim. The cult of the icon began to gain popularity at the turn of the fifteenth and sixteenth centuries and in 1511 the local duke, Fedor Yaroslavovich, donated a plot of woodland to the monastery which held this treasure. It is difficult to say whether this cult was connected with increasing threats of Tatar aggression. ${ }^{42}$

In sum we may conclude that during the fifteenth and early sixteenth centuries war against the Tatars and later the Turks and increasingly the Muscovites impinged considerably on the Catholic and Orthodox populations of the Grand Duchy of Lithuania. War and its consequences made their mark on devotions (to St George, St Casimir, the Ten Thousand Military Martyrs) and church and chantry building; pilgrimage contributions were sidelined for rebuilding churches as well as castles destroyed by the Tatars. The spoils of war were displayed publicly

\footnotetext{
${ }^{38}$ VMPL II, no. 240, p. 219; 242, p. 220.

${ }^{39}$ G. Kirkienè, LDK politikos elito galingieji: Chodkevičiai XV-XVI amžiuje, Vilnius, 2008, pp. 82-83.

${ }^{40}$ M. Starnawska, 'Mikołaj z Wyrozębów - obrońca Kijowa przed Tatarami i jego suplika do papieża o przekazanie relikwii z 1496 roku', in Między Polską a Rusią, ed. M. Starnawska, Siedlce, 2004, pp. 51-62.

${ }^{41}$ D. Ostrowski, Muscovy and the Mongols. Cross-cultural influences on the steppe frontier, 13041589, Cambridge, 1998, p. 170.

42 P. Chomik, Kupiatycka ikona Matki Bożej. Historia i literatura, Białystok, 2008, pp. 15-29.
} 
in Vilnius cathedral and thanksgiving for victory and intercession for the fallen took physical form in the building of churches by both Catholic and Orthodox leaders. Growing traditions of organising public processions around the city of Vilnius placed the Kletsk memorial church of St George clearly on the annual calendar. In the documentary record war was both a literary topos and a harsh everyday reality.

\section{Summary}

During the fifteenth and early sixteenth centuries war against the Tatars and later the Turks and increasingly the Muscovites impinged considerably on the Catholic and Orthodox populations of the Grand Duchy of Lithuania. War had consequences for religious devotion (to St George, St Casimir, the Ten Thousand Military Martyrs) and church and chantry building; pilgrimage contributions were sidelined for rebuilding churches as well as castles destroyed by the Tatars. The spoils of war (captured enemy banners) were displayed publicly in the cathedral in Vilnius (Vilna, Wilno) and thanksgiving for victory and intercession for the fallen took physical form in the building of churches and monasteries by both Catholic and Orthodox leaders. Personal and patriotic memory of the dead was visualised publicly in religious buildings. Growing traditions of organising public processions around the city of Vilnius placed the Kletsk (Kleck) memorial church of St George clearly on the burghers' annual calendar and historical memory.

\section{Karas ir dievobaimingumo išraiškos Lietuvos Didžiojoje Kunigaikštystèje vèlyvesniais viduramžiais Santrauka}

XV-XVI a. sandūroje padaugèjus totorių, turkų bei maskolių užpuolimų prieš Lietuvos didžiosios kunigaikštystės teritoriją, pastarosios katalikų ir stačiatikių bendruomenės susidūre tiesiogiai su karo smurtu. Karas turejjo nemažų pasekmių ir tuomet jau gyvybingam vietiniam religiniam gyvenimui. Padidejo pagarba karingiems šventiesiems Jurgui, Kazimierui, šventiesiems 10000 karių-kankinių; vyko bažnyčių bei altorių steigimas; maldininkų aukos Bažnyčiai perleidžiamos totorių išniokotų šventyklų ir pilių remontui. Vilniaus katedroje viešai kabo užkariautų priešų vèliavos, o padèkos Dievui už pergalę, maldos už žuvusiųjų išganymą akivaizdžiai ịsikūnijo bažnyčių, vienuolijų, cerkvių statybose. Vilniaus mieste įsitvirtinus tradicijai vesti viešas procesijas tarp dvasinių įstaigų; Klecko mūšio paminklas, šv. Jurgio bažnyčia ịsišaknijo miestiečių istorinejje atmintyje.

\section{Bibliography}

\section{Primary Sources}

Acta primae visitationis diocesis Vilnensis anno Domini 1522 peractae. Vilniaus Kapitulos archyvo Liber IIb atkūrimas, ed., introduction and commentary S.C. Rowell, Vilnius, 2015, Historiae Lituaniae fontes minores, vol. 8.

Acta Tomiciana. Tomus tertius epistolarum, legationum, responsorum, actionum et rerum gestarum

Serenissimi Principis Sigismundi Primi, Regis Polonie et Magni Ducis Lithuanie, Posnaniae, 1853. Ankstyvieji Šs Kazimiero Gyvenimai, ed. M. Čiurinskas, Vilnius, 2004. 
Bullarium Poloniae, vol. 7, ed. I. Sułkowska-Kuraś, S. Kuraś et al., Rome and Lublin, 2006.

The Chronicle of Battle Abbey, trans. E. Searle, Oxford, 1980.

Ioannis Dlugossii, Annales seu cronicae incliti regni Poloniae, liber decimus et liber undecimus 14061412, ed. D. Turkowska, Warsaw, 1997.

Ioannis Dlugossii, Annales seu cronicae incliti regni Poloniae, liber undecimus et liber duodecimus 1431-1444, ed. D. Turkowska, Kraków, 2001.

Ioannis Dlugossii, Annales seu cronicae incliti Regni Poloniae. Liber duodecimus 1462-1480, ed. D. Turkowska, Kraków, 2005.

Kodeks dyplomatyczny katedry i diecezji wileńskiej, ed. J. Fijałek and W. Semkowicz, Kraków, 19321948.

Polnoe sobranie russkikh letopisei, vol. 35, Moscow, 1980.

Sobranie drevnikh gramot i aktov gorodov Vil'ny, vol. 2, Vil'na, 1843.

Vetera Monumenta Poloniae et Lithuaniae gentiumque finitimarum historiam illustrantia, vol. 2, ed. A. Theiner, Romae, 1861 (2nd edn - Osnabrück, 1969).

\section{Secondary Sources}

Baronas D., Vilniaus pranciškonu kankiniai ir ju kultas XIV-XX a., Vilnius, 2010.

Brazgunoŭ A., 'Perekladnaia literatura ŭ Vialikim Kniaztve Litoŭskim u XV-XVIII stagoddziakh', Senoji Lietuvos literatūra, 21, 2006, pp. 193-99.

Chodynicki K., Kościót prawosławny a Rzeczpospolita Polska. Zarys historyczny 1370-1632, Warsaw, 1934 (2nd edn - Białystok, 2005).

Chomik P., Kupiatycka ikona Matki Bożej. Historia i literatura, Białystok, 2008.

Czyżewski K.J., 'Marso aidai Krokuvos katedroje', in Kaip tai atsitiko Didžiajame mūšyje... Žalgirio atodangos, ed. V. Dolinskas and B. Verbiejūtè, Vilnius, 2010, pp. 44-66.

Čiurinskas M., 'Karas ir kultūra Lietuvos Didžiojoje Kunigaikštysteje: 1514 metai', Senoji Lietuvos literatūra, 31, 2011: Istoriniai mūšiai senojoje Lietuvos raštijoje: Žalgiris ir Orša, pp. 127-80.

Čiurinskas M., 'Pergalès prie Oršos (1514) propaganda Europoje: Šaltinių apžvalga, literatūriniai ir kultūriniai aspektai', Senoji Lietuvos literatūra, 21, 2006, pp. 317-41.

Dolinskas V., 'Vilniaus katedra - karinių pergalių minejjimo ir įamžinimo vieta', in Kaip tai atsitiko Didžiajame mūšyje... Žalgirio atodangos, ed. V. Dolinskas and B. Verbiejūtė, Vilnius, 2010, pp. 87-101.

Ekdahl S., 'Pobojowisko grunwaldzkie i okolica w XV i XVI stuleciu', Studia Grunwaldzkie, 3, 1994, pp. 61-115.

Eubel K., Hierarchia Catholica medii [et recentioris] aevi, vol. 2, Münster, 1914; vol. 3, Münster, 1924.

Jasas R., Pergamentu katalogas, Vilnius, 1980.

Kirkienè G., LDK politikos elito galingieji: Chodkevičiai XV-XVI amžiuje, Vilnius, 2008.

Kloza J., Maroszek J., Dzieje Goniądza w 450 rocznice praw miejskich, Białystok and Goniądz, 1997, Prace Białostockiego Towarzystwa Naukowego, no. 37.

Kurczewski J., Kościół zamkowy czyli katedra wileńska w jej dziejowym, liturgicznym, architektonicznym i ekonomicznym rozwoju, t. 3, Wilno, 1912.

Lietuvos kataliku dvasininkai XIV-XVI a., ed. V. Ališauskas, T. Jaszczołt, L. Jovaiša and M. Paknys, Vilnius, 2009, Bažnyčios istorijos studijos, vol. 2.

Maslauskaitė S., Šv Kazimiero atvaizdo istorija, Vilnius, 2010.

Matusas J., Švitrigaila Lietuvos didysis kunigaikštis, Kaunas, 1938 (2nd edn - Vilnius, 1991).

Ochmański J., Biskupstwo wileńskie w średniowieczu. Ustrój i uposażenie, Poznań, 1972.

Ostrowski D., Muscovy and the Mongols. Cross-cultural influences on the steppe frontier, 1304-1589, Cambridge, 1998. 
Potkowski E., 'Monarsze dary książkowe w polskim średniowieczu - pogrunwaldzkie dary Jagiełły', in Ojczyzna bliższa i dalsza. Studia historyczne ofiarowane Feliksowi Kirykowi w sześćdziesiąta rocznicę urodzin, ed. J. Chrobaczyński et al., Kraków, 1993, pp. 359-73.

Rowell S.C., 'Kaip šaukè, taip ir atsiliepė: XV a. lietuvių katalikų gyvenimas ir pagonybès liekanų mitas', in Lietuvos Didžiosios Kunigaikštystés istorijos kraštovaizdis. Moksliniu straipsniu rinkinys, skirtas profesorès Jūratès Kiaupienès 65-mečiui, ed. R. Šmigelskytè-Stukienè, Vilnius, 2012, pp. 295-320.

Rowell S.C., 'Naujieji kryžiaus žygiuotojai: LDK ir Bizantijos santykiai XIV-XV a. sandūroje. Ar Vytautas Didysis buvo Lietuvos kryžiaus žygių prieš turkus bei totorius pradininkas?', in Kryžiaus karu epocha Baltijos regiono tautu istorineje sąmonejje. Moksliniu straipsnių rinkinys, ed. R.R. Trimoniené and R. Jurgaitis, Šiauliai, 2007, pp. 181-205.

Rowell S.C., 'Nevisai primintinos kautynès: ką byloja šaltiniai apie 1399 m. mūš ties Vorsklos upe?', Istorijos šaltiniu tyrimai, 1, 2008, pp. 67-90.

Rowell S.C., 'XV a. LDK ir totorių santykiai Katalikų Bažnyčios akimis XV a.: prielaidos ir poveikis', in Vidurio rytu Europa müšio prie Mèlynujų Vandenu metu, ed. V. Jankauskas and V. Nagirnyy, Kaunas and Kraków, 2013, Colloquia Russica, ser. 2, vol. 2, pp. 227-33.

Sahanovich H.M., Ajchynu svaiu baroniachy: Kanstantsin Astrozhski, Mensk, 1992.

Slovar' knizhnikov i knizhnosti Drevnei Rusi. XI-pervaia polovina XIV v., ed. D.S. Likhachev, Leningrad, 1987.

Smołucha J., 'Udział pielgrzymów z Królestwa Polskiego i Wielkiego Księstwa Litewskiego w obchodach średniowiecznych jubileuszów chrześcijaństwa', Nasza Przeszłość, 93, 2000, pp. 5-21.

Starnawska M., 'Mikołaj z Wyrozębów - obrońca Kijowa przed Tatarami i jego suplika do papieża o przekazanie relikwii z 1496 roku', in Między Polską a Rusią, ed. M. Starnawska, Siedlce, 2004, pp. 51-62.

Starnawska M., Świętych życie po życiu. Relikwie w kulturze religijnej na ziemiach polskich $w$ średniowieczu, Warsaw, 2008.

Trimoniene R., 'Kryžiaus karų idejja XV a. II pusejje ir Lietuvos Didžioji Kunigaikštystë, in Kryžiaus karu epocha Baltijos regiono tautu istorineje sąmonëje. Moksliniu straipsnių rinkinys, ed. R.R. Trimoniené and R. Jurgaitis, Šiauliai, 2007, pp. 223-32.

S.C. Rowell - PhD (Cantab.), Senior Researcher at the Lithuanian Institute of History in Vilnius; specialising in the late medieval political and religious history of the Grand Duchy of Lithuania. E-mail: karunakalv@yahoo.co.uk 